\title{
A study to assess the knowledge regarding rabies prevention among general population of community residing at Pratap Nagar, Jodhpur, Rajasthan
}

\section{Vandna Pandey $^{1 *}$, Nancy Kurien ${ }^{1}$, Sangeeta Ghintala ${ }^{2}$, Sharda Saini ${ }^{2}$, Shivani Chauhan ${ }^{3}$, Shweta Sharma ${ }^{2}$, Sonali Sharma ${ }^{4}$, Suman Kachhawaha ${ }^{2}$, Suman Gurjar ${ }^{5}$, Suman Bhatiya ${ }^{2}$}

${ }^{1} \mathrm{CON}$, AIIMS, Rajasthan, India

${ }^{2}$ AIIMS, Jodhpur, Rajasthan, India

${ }^{3}$ AIIMS, New Delhi, India

${ }^{4}$ ILBS, New Delhi, India

${ }^{5}$ AIIMS, Kalyani, West Bengal, India

Received: 08 May 2021

Accepted: 05 June 2021

\section{*Correspondence:}

Ms. Vandna Pandey,

E-mail:drmvkshirsagar@yahoo.co.in

Copyright: (c) the author(s), publisher and licensee Medip Academy. This is an open-access article distributed under the terms of the Creative Commons Attribution Non-Commercial License, which permits unrestricted non-commercial use, distribution, and reproduction in any medium, provided the original work is properly cited.

\begin{abstract}
Background: Rabies is a major public health issue. It is 10th biggest cause of death due to infectious disease worldwide and continues to be a burden for India with the country still registering around 18,000 to 20,000 cases of rabies every year. It is the only communicable disease of man that is always fatal. Domestic dogs are most common reservoir of virus, with $99 \%$ of human death caused by dog mediated rabies. Rabies is completely curable by early diagnosis and treatment regimen.

Methods: Present study has been carried out among general population of community residing at Pratap Nagar, Jodhpur, and Rajasthan. Quantitative research approach was used to assess the knowledge regarding rabies prevention. Data was collected through self-structured interview schedule. Sixty samples were selected by non -probability convenient sampling technique.

Results: In the study there were 60 subjects, in which male were 28 and female were 32.7 subjects had excellent knowledge, 34 subjects had good knowledge, 17 subjects had average knowledge and 2 subjects had poor knowledge. No personal variable was found to be in association with level of knowledge at $\mathrm{p}<0.05$ level of significance.

Conclusions: The study indicates that awareness session on rabies prevention should be held regularly to improve the knowledge and create positive attitude and remove the misconception among general population.
\end{abstract}

Keywords: Assess, Knowledge, Rabies, Prevention, General population, Community

\section{INTRODUCTION}

Rabies, also known as hydrophobia, is an acute viral disease that affects central nervous system, causing acute encephalitis in warm blooded animals including mammals. ${ }^{1}$ The virus responsible for rabies is Lyssavirus type I (which is derived from the Greek word lyssa meaning 'madness'). ${ }^{2}$

Rabies is estimated to cause 59,000 human deaths annually in over 150 countries, with $95 \%$ of cases occurring in the Asia and Africa regions. In Asia estimated human deaths due to rabies are 35,172 per year. India accounts for $59.9 \%$ of rabies death in Asia and $35 \%$ of 
death globally. ${ }^{3}$ In bulletin of the WHO (2014), India reportes about 18,000 to 20,000 cases of rabies each year. WHO bulletin also shows a study conducted by Sudarshan MK (2005) to assess the burden of human rabies in India. In which $70 \%$ of the people in India have never heard of rabies, only $30 \%$ know how to wash the wounds after animal bites, and those who get bitten, only $60 \%$ receive a modern cell culture derived vaccine. It is the only communicable disease of man that is always fatal. Domestic dogs are most common reservoir of virus, with $99 \%$ of human death caused by dog mediated rabies. Although all age groups are susceptible, rabies is most common in children aged less than 15 years. ${ }^{4}$ In India, rabies affects mainly people of lower socioeconomic status. ${ }^{5}$ There are many myths and false beliefs associated with wound management present among people. ${ }^{6}$ The source of infection to man is the saliva of rabid animals. In dogs the virus may be present in the saliva for 3-4 days before the onset of clinical symptoms and during the course of illness till death. People are infected following a deep bite or scratch by an infected animal. Once virus of rabies is inside the body, it replicates in muscles or connective tissue cells at wound site gaining access to peripheral nerve then to central nervous system and multiplies there. Once virus reaches brain, its further replicates and results in encephalitis. ${ }^{1}$

The incubation period in dogs ranges from 3-8 weeks, but it may be as short as 10 days or a year or more. Clinical manifestations in dog with rabies are change in behavior (become aggressive), biting without provocation, change in voice, excessive salivation, eating abnormal items like stick, nail, mud etc. ${ }^{1}$ Clinical manifestation in man are in two forms which include 'furious rabies' that exhibit the classic signs of hyperactivity, agitation, hydrophobia, aerophobia, with death occurring within two to three days and 'paralytics' or 'dumb rabies' that is less dramatic and causes death from muscular paralysis. ${ }^{7}$

Almost all human cases of rabies were fatal until a vaccine was developed in 1885 by Louis Pasteur and Emile Roux. ${ }^{8}$ There is no effective curative treatment for rabies once clinical signs have appeared. Treatment and prevention of rabies is done by case management, local treatment of wound, immunization, and pre and post exposure prophylaxis. In case of rabies in dogs, prophylactic vaccination of dogs against rabies is one of the most important weapons in rabies control. Other methods are registration and licensing of domestic dogs, restraints of dogs in public places, quarantine for about 6 months of imported dogs, health education to people regarding dog care, immunization, and rabies prevention. ${ }^{1}$ WHO promotes mass dog vaccination campaigns, dog population management, and oral vaccination for domestic carnivores. WHO also promotes wide access to appropriate post-exposure treatment, domestic production of rabies biological (particularly immunoglobulin), continual health education to public and veterinary professional in rabies prevention and control. ${ }^{9}$

\section{METHODS}

The present study was carried out to assess the knowledge regarding rabies prevention in community, Pratap Nagar, Jodhpur, Rajasthan. In this study, quantitative research approach was used to assess the knowledge regarding rabies prevention in community, Pratap Nagar, Jodhpur, Rajasthan. The population was general population under age group 18 to 60 years of age residing in urban area of Pratap Nagar, Jodhpur, Rajasthan. Non-Probability Convenient sampling technique was adopted for this study. The self-structured questionnaire method was adopted for data collection. Self-structured knowledge questionnaire was prepared for assessing the knowledge of general population regarding prevention of rabies based on the review of research and non-research literature and opinion of experts.

The data was collected using self-structured questionnaire consisting of two parts: (a) Part A-items of demographic variables like age, gender, education, economic status; and (b) Part B- self-administered questionnaire on knowledge regarding prevention of rabies. Self-administered questionnaire had 30 questions for assessing the knowledge regarding rabies prevention, every correct answer was given a score of 1 , and incorrect answer was given score of zero. Unanswered response was marked as 0 . The domains of the questionnaire were- general awareness about rabies, primary prevention, secondary prevention and tertiary prevention. Table 1 shows the weightage of questions in self -administered questionnaire with regard to domains.

Table 1: Domain wise weightage of self-administered questionnaire.

\begin{tabular}{|ll|}
\hline Domains & Weightage (\%) \\
\hline General awareness & 40 \\
\hline Primary prevention & 16.67 \\
\hline Secondary prevention & 36.67 \\
\hline Tertiary prevention & 6.66 \\
\hline
\end{tabular}

Validity of the tool was established by opinion of panel of experts. Suggestion of the experts was incorporated and tools were modified accordingly. The reliability of the tool was tested through Kuder-Richardson formula 20. The reliability for the self-structured tool was found to be 0.68 . Thus, tool was found to be reliable.

\section{RESULTS}

The analysis of data is presented in the following section. For analysis and interpretation of the collected data, descriptive and inferential statistics were used. The statistical analysis was done by SPSS 23 version. The data were summarized as mean, frequency, percentage and standard deviation. The Chi square test was used to test the association. 


\section{Findings related to demographic variables of general population residing at Pratap Nagar, Jodhpur, Rajasthan}

Table 2 depicts that $46.66 \%$ of subjects were male and $53.33 \%$ were female. $40 \%$ subjects were in age group of $18-28$ years, whereas $15 \%$ were in age group of $29-39$ years, $16.66 \%$ were in the age group of $40-50$ years and $28.33 \%$ were in age group of 51-60 years.

As regard to family income, $70 \%$ subjects had family income less than rupees $10000,18.33 \%$ subjects had family income between rupees 10000 to $35000,8.33 \%$ subjects had family income between rupees 36000-60000 and $3.33 \%$ subjects had family income more than rupees 60000 per month.

Educational status- $13.33 \%$ had no formal education, $15 \%$ had primary education, $28.33 \%$ had secondary and senior secondary education and $43.33 \%$ had graduation degree and above.

Table 2: Frequency and percentage distribution of demographic variables.

\begin{tabular}{|lll|}
\hline Variables & Frequency & Percentage (\%) \\
\hline Age (years) & & \\
\hline 18 to 28 & 24 & 40 \\
\hline 29 to 39 & 9 & 15 \\
\hline 40 to 50 & 10 & 16.66 \\
\hline 51 to 60 & 17 & 28.33 \\
\hline Gender & & \\
\hline Male & 28 & 46.66 \\
\hline Female & 32 & 53.33 \\
\hline Education & & \\
\hline No formal education & 8 & 13.33 \\
\hline Primary education & 9 & 15 \\
\hline $\begin{array}{l}\text { Secondary and senior } \\
\text { secondary education }\end{array}$ & 17 & 28.33 \\
\hline $\begin{array}{l}\text { Graduation and above } \\
\text { Economic status (Rs.) }\end{array}$ & 26 & 43.33 \\
\hline Less than 10,000 & 42 & \\
\hline 10,000 to 35,000 & 11 & 70 \\
\hline 36,000 to 60,000 & 5 & 8.33 \\
\hline More than 60,000 & 2 & 3.33 \\
\hline
\end{tabular}

\section{Findings related to knowledge of the general population residing at Pratap Nagar, Jodhpur, Rajasthan}

Knowledge regarding prevention of rabies was assessed by self-structured interview schedule consisting of 30 questions After obtaining data of 60 samples, the grading of the score was done out of the total score of 30 .

\section{Scoring}

Correct response is scored as 1 , incorrect response is marked as 0 and unanswered response is marked as 0 .
Table 3 depicts that $13.33 \%$ people had poor knowledge (12 or $<12$ i.e.; $<40 \%$ ), $36.66 \%$ had average knowledge (13 to 18 i.e.; $41-60 \%$ ), $46.66 \%$ had good knowledge (19 to 24 i.e.; $61-80 \%$ ) and $3.33 \%$ had excellent knowledge (25 to 30 i.e.; $81-100 \%)$.

Table 3: Mean percentage score of various domains of self -administered questionnaire.

\begin{tabular}{|lll|}
\hline Domains & Mean (\%) & SD \\
\hline General awareness & 64.58 & 1.8651578 \\
\hline Primary prevention & 53.6 & 1.2952543 \\
\hline $\begin{array}{l}\text { Secondary } \\
\text { prevention }\end{array}$ & 60.27 & 2.0908734 \\
\hline Tertiary prevention & 63 & 0.8206378 \\
\hline
\end{tabular}

Table 4 shows the mean percentage score of questions related to various domains of self-administered questionnaire. Mean percentage score of general awareness is $64.58 \%$ with SD of 1.86 .

Mean percentage score of questions regarding primary prevention is $53.6 \%$ with SD of 1.29 , whereas mean percentage score of domains related to secondary and tertiary prevention were $60.27 \%$ and $63 \%$ with SD of 2.090 and 0.820 respectively.

\section{Findings related to association between knowledge score and demographic variables}

To determine the significant association between knowledge score of subjects with selected demographic variables, following research variables were selected: age, gender, education and economic status.

Table 5 depicts that no personal variable was found to be associated with level of knowledge at $p<0.05$ level of significance.

\section{Major findings}

(a) Gender: $46.66 \%$ of subjects were male and $53.33 \%$ were female; (b) Educational status: $13.33 \%$ had no formal education, $15 \%$ had primary education, $28.33 \%$ had secondary and senior secondary education and $43.33 \%$ had graduation degree and above; (c) Age: $40 \%$ subjects were in age group of $18-28$ years, whereas $15 \%$ were in age group of 29-39 years, $16.66 \%$ were in the age group of 40 50 years and $28.33 \%$ were in age group of 51-60 years; (d) Family income: $70 \%$ subjects had family income less than rupees $10000,18.33 \%$ subjects had family income between rupees 10000 to $35000,8.33 \%$ subjects had family income between rupees $36000-60000$ and $3.33 \%$ subjects had family income more than rupees 60000 per month; (e) Level of knowledge - $13.33 \%$ people had poor knowledge (12 or < 12 i.e.; $<40 \%$ ), $36.66 \%$ had average knowledge (13 to 18 i.e.; $41-60 \%$ ), $46.66 \%$ had good knowledge (19 to 24 i.e.; $61-80 \%$ ) and $3.33 \%$ had excellent knowledge (25 to 
30 i.e.; 81-100\%); and (f) Association of knowledge score of subjects with selected variables- no personal variable was found to be associated with level of knowledge at $\mathrm{p}<0.05$ level of significance.

Table 4: Criteria to assess knowledge level, frequency, percentage, mean and standard deviation of findings.

\begin{tabular}{|c|c|c|c|c|}
\hline Criteria to assess knowledge level & Frequency & Percentage $(\%)$ & Mean & SD \\
\hline Excellent (25-30 i.e.; 81-100\%) & 2 & 3.33 & \multirow{4}{*}{18.33} & \multirow{4}{*}{4.1739} \\
\hline Good (19 to 24 i.e.; 61-80\%) & 28 & 46.66 & & \\
\hline Average (13 to 18 i.e.; 41-60\%) & 22 & 36.66 & & \\
\hline Poor (12 or less than 12 i.e.; $<40 \%$ ) & 8 & 13.33 & & \\
\hline
\end{tabular}

Table 5: Association of level of knowledge score and selected socio-demographic variables.

\begin{tabular}{|c|c|c|c|c|c|c|c|c|}
\hline \multirow{2}{*}{ Variables } & \multicolumn{4}{|c|}{ Knowledge level } & \multirow{2}{*}{$\begin{array}{l}\text { Chi } \\
\text { square }\end{array}$} & \multirow{2}{*}{$\begin{array}{l}\text { Table } \\
\text { value }\end{array}$} & \multirow{2}{*}{$\begin{array}{l}\text { Degree } \\
\text { of } \\
\text { freedom }\end{array}$} & \multirow{2}{*}{$\begin{array}{l}\text { Significant/ } \\
\text { non- } \\
\text { significant }\end{array}$} \\
\hline & $\mathbf{E}$ & $\mathbf{G}$ & A & $\mathbf{P}$ & & & & \\
\hline \multicolumn{9}{|l|}{ Age (years) } \\
\hline 18 to 28 & 1 & 7 & 12 & 4 & \multirow{4}{*}{8.35} & \multirow{4}{*}{16.92} & \multirow{4}{*}{9} & \multirow{4}{*}{$\begin{array}{l}\text { Non- } \\
\text { significant }\end{array}$} \\
\hline 29 to 39 & 1 & 5 & 2 & 1 & & & & \\
\hline 40 to 50 & 0 & 7 & 2 & 1 & & & & \\
\hline 51 to 60 & 0 & 9 & 6 & 2 & & & & \\
\hline \multicolumn{5}{|l|}{ Gender } & \multirow{3}{*}{1.87} & \multirow{3}{*}{7.82} & \multirow{3}{*}{3} & \multirow{3}{*}{$\begin{array}{l}\text { Non- } \\
\text { significant }\end{array}$} \\
\hline Male & 1 & 14 & 8 & 5 & & & & \\
\hline Female & 1 & 14 & 14 & 3 & & & & \\
\hline \multicolumn{5}{|l|}{ Education } & \multirow{4}{*}{11.83} & \multirow{4}{*}{16.92} & \multirow{4}{*}{9} & \multirow{4}{*}{$\begin{array}{l}\text { Non- } \\
\text { significant }\end{array}$} \\
\hline No formal education & 0 & 3 & 4 & 1 & & & & \\
\hline Primary education & 0 & 3 & 5 & 1 & & & & \\
\hline Secondary and senior secondary education & 0 & 6 & 6 & 5 & & & & \\
\hline Graduation and above & 2 & 16 & 7 & 1 & \multirow{6}{*}{5.04} & \multirow{6}{*}{16.92} & \multirow{6}{*}{9} & \multirow{6}{*}{$\begin{array}{l}\text { Non- } \\
\text { significant }\end{array}$} \\
\hline \multicolumn{5}{|l|}{ Economic status (Rs.) } & & & & \\
\hline Less than 10,000 & 2 & 17 & 17 & 6 & & & & \\
\hline 10,000 to 35,000 & 0 & 6 & 3 & 2 & & & & \\
\hline 36,000 to 60,000 & 0 & 3 & 2 & 0 & & & & \\
\hline More than 60,000 & 0 & 2 & 0 & 0 & & & & \\
\hline
\end{tabular}

E-excellent, G-good, A-average, P-poor.

\section{DISCUSSION}

This study was conducted to assess the knowledge regarding rabies prevention among general population of Pratap Nagar, Jodhpur, Rajasthan.

The study reveals that $13.33 \%$ people had poor knowledge and $36.66 \%$ only had average knowledge regarding rabies prevention. The current results were supported by study conducted by Herbert et al (2010). ${ }^{12}$ The study was conducted on community perception regarding rabies prevention. The study results show that $74.1 \%$ of the participants had heard about rabies and $54.1 \%$ knew that rabies is a fatal disease. Only $33.5 \%$ of the interviewers felt that people in community had a role to play in controlling the stray dog population.

Approximately one half of the residents did not know about the correct first aid after an animal bite. Similar results were found by Prakash et al (2011). ${ }^{13}$ A cross sectional study was conducted to assess knowledge, attitude, and practice about rabies and control among the population of urban slums area of Pune.

Among 200 respondents only $23 \%$ had knowledge about rabies transmission. Laishram J et al (2013-2014) carried a cross-sectional study on knowledge and practice on rabies among the adult residents in an urban community of Imphal, Manipur, India. ${ }^{14} \mathrm{~A}$ total of 350 respondents participated in study. Among those, $97.1 \%$ had ever heard of rabies, and only $8.6 \%$ knew that it was caused by virus. More than half of the respondents $51.5 \%$ had inadequate knowledge related to rabies.

\section{Limitations}

The study was confined to a small number of 60 samples which limit the generalization of the findings. The study was confined to urban community of Jodhpur. 


\section{CONCLUSION}

The study findings revealed that there existed deficiency in knowledge of subjects regarding prevention of rabies. Awareness regarding rabies prevention in community need to be increased by undertaking IEC activities and targeted awareness campaigns.

The community people can be counselled regarding nature of provocative behavior of animals, immediate washing of wound with soap and running water for at least 15-20 minutes as soon as possible, early initiation of medical treatment and resolve any myths regarding dog bite. Community with improved knowledge about rabies and its prevention will result in healthier attitudes and beliefs and ultimately in safer practice.

\section{Recommendations}

On the basis of findings of study, it is recommended that the study can be replicated on a large sample for generalization. A similar study can be conducted with experimental research approach.

Funding: No funding sources

Conflict of interest: None declared

Ethical approval: The study was approved by the Institutional Ethics Committee

\section{REFERENCES}

1. Park K. Park's Textbook of Preventive and Social Medicine. 24th ed. Jabalpur: Bhanot publishers; 2017: 294-299.

2. Zuckerman AJ. In: Bantaval JE, Griffiths P, Schoub B, eds. Principles and Practice of Clinical Virology. 6th ed. UK: John Wiley and Sons; 2009: 778.

3. WHO. Epidemiology and burden of disease, 2018. Available at: https://www.who.rabies/epidemiology/ en/. Accessed on 1 May 2021.

4. WHO. Human rabies in India: a problem needs more attention, 2019. Available at: https://www.who.int/ bulletin/volumes/92. Accessed on 1 May 2021.

5. Menezes R. Rabies in India. CMAJ. 2008;178(5):564-6.

6. Singh US, Choudhary SK. Knowledge, Attitude, Behavior and Practice Study on Dog-Bites and Its Management in the Context of Prevention of Rabies in a Rural Community of Gujarat. Indian J Community Med. 2005;30:81-3.

7. Sharma S. Vaccine preventable rabies is India's most fatal infection, 2018. Available at: https://www.hindustantimes.com/health/vaccineprev entable-rabies-is-india-s-most-fatal -infection/storyle3H2DE4wSZPk1EqXR6WmJ.html. Accessed on 1 May 2021.

8. Wikipedia. Rabies vaccine, 2018. Available at: https://en.m.wikipedia.org/wrabiesvaccine. Accessed on 1 May 2021.
9. WHO. The disease: Prevention, 2019. Available at: https://www.who.int/rabies/about/ homeprevention/en/. Accessed on 1 May 2021.

10. WHO. Rabies: Recommended PEP, 2018. Available at: https://www.who.int/news-room/factsheets/detail/rabies. Accessed on 1 May 2021.

11. Global Alliance for Rabies Control. Rabies: Share the message. Save a life, 2018. Available at: https://rabiesalliance.org/world-rabies-day. Accessed on 1 May 2021.

12. Herbert M, Riyaz BS, Thangaraj S. Community perception regarding rabies prevention and stray dog control in urban slums in India. J Infect Public Health. 2012;5(6):374-80.

13. Prakash M, Bhatti VK, Venkatesh G. Rabies menace and control - An insight into knowledge, attitude and practices. Med J Armed Forces India. 2013;69(1):57-60.

14. Laishram J. Knowledge and Practice on rabies in an urban community of Manipur, India. J Evaluation Med Dent Sci. 2016;5(37):2234-7.

15. Sancheti PV, Mangulikar SK. An interventional study to asses knowledge regarding rabies in secondary school students. Int $\mathbf{J}$ Community Med Public Health. 2016;3:180-3.

16. Singh M, Upaadhya SK, Bhansali S, Saini JP. Animal bite cases in Western Rajasthan, India: A Retrospective study. SAJB. 2016;4(6):483-7.

17. Lavania D. District hospital out of anti-rabies vaccine stock since last month, 2018. Available at: https://m.timesofindia.com/city/agra/districthospitalout-of-anti-rabies-vaccine-stockmonth/articleshow. Accessed on 1 May 2021.

18. Times of India. Denied anti-rabies vaccine, ambulance at govt hospital 12 year old student dies. Times of India, 2019. Available at: https://m.timesof india.com/city/bareill-ant-rabies-vaccineambulance govt12-year-old-student-dies/articleshow. Accessed on 1 May 2021.

19. Totton SC, Wandeler AI, Zinsstag J, Bauch CT, Ribble CS, Rosatte RC, et al. Stray dog population demographics in Jodhpur, India following a population control/rabies vaccination program. Prev Vet Med. 2010;97(1):51-7.

20. Mishra N. Every year 6 thousand people bitten by dog. Patrika, 2018. Available at: http://m.partika.com/jodhpur-news/everythousandpeople-bitten-by-dog-in-jodhpur-2326589. Accessed on 1 May 2021.

21. Polit DF, Beck CT. Essentials of nursing research: appraising evidence for nursing practice. 8th ed. New Delhi: Wolter Kluwer; 2015: 52.

22. Tiwari A. Assessment of Knowledge regarding Rabies and its prevention among the medical students of government medical college Rajnand gaon, Chhattisgarh, India. Int J Community Med Public Health. 2018;5(4):1397-401.

23. Tandan S, Kotwal SK, Malik MA, Singh M, Kumar $\mathrm{D}$, Shaqif $\mathrm{M}$, et al. A community based survey on 
Rabies control and prevention in Jammu, India. J Animal Res. 2017;7(6):1019-28.

24. Tripathy RM, Satapathy SP, Karmee N. Assessment of knowledge, attitude and practice regarding rabies and its prevention among construction workers: a cross-sectional study in Berhampur, Odisha. Int J Res Med Sci. 2017;5:3970-5.

25. Chopra D. Assessment of awareness about rabies and the animal bites among the staff nurses in medical institute in Lucknow. Int J Community Med Public Health. 2017;4(6):2046-51.

26. Balakrishnan S. Knowledge level and attitude on rabies and dog bite management among rural people in orathanadu, Tamil Nadu. JEZS. 2017;6(2):1963-7.

27. Mali A, Solanki SL. An Assessment of prevention and management of rabies in second year MBBS students of American International Institute of Medical Sciences, Udaipur. IJCRR. 2018;10(6):2231-96.

28. Muthunuwan JT, Ganheva AG, Perera HD, Hishaam M, Bandara WM, Gunashekere HA. Preliminary survey on knowledge, attitudes and practices regarding rabies. 2017;7(1):38-46.

29. Chandan N, Kotrabasappa K. Awareness of animal bite and rabies among agricultural workers in rural Dharwad, Karnataka, India. Int J Community Med Public Health. 2016;3:1851-5.

30. Dabuma T, Kabeta T, Mengist HM. Assessment of Basic Knowledge, Attitude and Practice of Community on Rabies and Retrospective Survey in and around Ambo Town, West Shoa Zone of Ethiopia. J Med Microb Diagn. 2017;6:263.

31. Singh R. Knowledge, Attitude and Practice assessment in health workers regarding rabies disease and its prevention in district Dehradun, Uttarakhand. Indian J Comm Health. 2015;27(2):381-5.

32. Mishra N, Solanki SL. Assessment of knowledge about rabies in interns of Geetanjali medical college, Udaipur. Int J Community Med Public Health. 2015;2(2):121-3.

33. Chouhan P, Saini G. Study of profile of animal bite victims attending anti-rabies clinic at Jodhpur. Int $\mathbf{J}$ Med Sci Public Health. 2013; 2(4):1088-91.
34. Shah SF, Jawed M, Nooruddin S, Afzal S, Sajid F, Majeed S, Naveed M, et al. Knowledge and practices among the general practitioners of Karachi regarding dog bite management. J Pak Med Assoc. 2009;59(12):861-4.

35. Ichhpujani RL, Chhabra M, Mittal V, Bhattacharya D, Singh J, Lal S. Knowledge, attitude and practices about animal bites and rabies in general community-a multi-centric study. J Commun Dis. 2006;38(4):355-61.

36. Digafe RT, Kifelew LG, Mechesso AF. Knowledge, attitudes and practices towards rabies: questionnaire survey in rural household heads of Gondar Zuria District, Ethiopia. BMC Res Notes. 2015;8:400.

37. Shen J, Li S, Xiang H, Pang S, Xu G, Schwebel DC. A multi-site study on knowledge, attitudes, beliefs and practice of child-dog interactions in rural China. Int J Environ Res Public Health. 2013;10(3):950-62.

38. Sarkar A, Sudip B, Chintan B, Gohel A, Naresh M, Parmar D. An Assessment of knowledge of prevention and management of Rabies in interns and final year students of Shri M. P. Shah Government Medical College, Jamnagar, Gujarat. J Res Med Den Sci. 2013;1(2):62-6.

39. Tenzin, Dhand NK, Rai BD, Changlo, Tenzin S, Tsheten K, Ugyen P, et al. Community-based study on knowledge, attitudes and perception of rabies in Gelephu, south-central Bhutan. Int Health. 2012;4(3):210-9.

40. Kotnis SD, Deshmukh SC. Knowledge and Practice Regarding Prevention and Management of Rabies among Allopathic and AYUSH private practitioners in Urban Maharashtra: A Comparison Study. Natl J Community Med. 2017;8(4):164-8.

Cite this article as: Pandey V, Kurien N, Ghintala S, Saini S, Chauhan S, Sharma S, et al. A study to assess the knowledge regarding rabies prevention among general population of community residing at Pratap Nagar, Jodhpur, Rajasthan. Int J Community Med Public Health 2021;8:3424-9. 